\title{
Activation and centromeric localization of CCAAT/enhancer-binding proteins during the mitotic clonal expansion of adipocyte differentiation
}

\author{
Qi-Qun Tang and M. Daniel Lane ${ }^{1}$ \\ Department of Biological Chemistry, Johns Hopkins University School of Medicine, Baltimore, Maryland 21205 USA
}

\begin{abstract}
Hormonal induction of 3T3-L1 preadipocytes triggers a cascade of events that initiate differentiation into adipocytes. CCAAT/enhancer-binding proteins $\beta$ and $\delta(C / E B P \beta / \delta)$ are expressed early in the differentiation program, but are not immediately active. After a long lag, $C / E B P \beta / \delta$ become competent to bind to the $C / E B P$ regulatory element in the $\mathrm{C} / \mathrm{EBP} \alpha$ gene promoter, $\mathrm{C} / \mathrm{EBP} \alpha$ being a transcriptional activator of numerous adipocyte genes. As $C / E B P \beta / \delta$ acquire binding activity, they become localized to centromeres as preadipocytes synchronously enter $S$ phase at the onset of mitotic clonal expansion. Localization to centromeres occurs through C/EBP consensus-binding sites in centromeric satellite DNA. C/EBP $\alpha$, which is antimitotic, becomes centromere-associated much later in the differentiation program as mitotic clonal expansion ceases and the cells become terminally differentiated.
\end{abstract}

[Key Words: 3T3-L1 preadipocyte; cell cycle; C/EBP; satellite DNA; centromere]

Received May 17, 1999; revised version accepted July 15, 1999.

$\mathrm{C} / \mathrm{EBP} \alpha(\underline{\mathrm{CCAAT}}$ / $\underline{\mathrm{e}} \mathrm{Chancer}-\underline{b}$ inding protein $\underline{\alpha})$ has a vital role in adipocyte differentiation (Cornelius et al. 1994; MacDougald and Lane 1995; Hwang et al. 1997). $\mathrm{C} / \mathrm{EBP} \alpha$ is not only required for differentiation (Samuelsson et al. 1991; Lin and Lane 1992), but along with $\operatorname{PPAR} \gamma$ (peroxisome proliferator-activated receptor- $\gamma$ ), is sufficient to activate the adpocyte differentiation program without the hormonal inducers normally required (Lin and Lane 1994; Brun et al. 1996). C/EBP $\alpha$ serves as a pleiotropic transcriptional activator coordinately inducing expression of numerous adipocyte genes that promote acquisition of the adipocyte phenotype (Herrera et al. 1989; Kaestner er al. 1990; Cheneval et al. 1991; Christy et al. 1989, 1991; Hwang et al. 1996). Two other members of the $\mathrm{C} / \mathrm{EBP}$ family of transcription factors, namely $\mathrm{C} / \mathrm{EBP} \beta$ and $\mathrm{C} / \mathrm{EBP} \delta(\mathrm{C} / \mathrm{EBP} \beta / \delta)$, also function in the differentiation program (Cao et al. 1991; Yeh et al. 1995). C/EBP $\beta / \delta$ are expressed early in the program (Cao et al. 1991; Yeh et al. 1995), whereas C/EBP $\alpha$ is expressed much later (Cao et al. 1991; Christy et al. 1991; Yeh et al. 1995). The proximal promoter of the $C / E B P \alpha$ gene contains a $\mathrm{C} / \mathrm{EBP}$ regulatory element that mediates transactivation by $\mathrm{C} / \mathrm{EBP} \beta / \delta$ (Christy et al. 1991). Thus, the C/EBP family appears to function in a cascade (Yeh et al. 1995) in which $\mathrm{C} / \mathrm{EBP} \beta / \delta$ initially activate transcription of the $C / E B P \alpha$ gene, after which $\mathrm{C} / \mathrm{EBP} \alpha$ coor-

${ }^{1}$ Corresponding author.

E-MAIL Dan.Lane@QMAIL.BS.JHU.EDU; FAX (410) 955-0903. dinately activates the expression of adipocyte genes producing the terminally differentiated state (Lin et al. 1993). Proof of the vital role played by the C/EBPs in adipogenesis in vivo was demonstrated by disruption of the $C / E B P \alpha$ gene (Wang et al. 1995) or both of the $C / E B P \beta$ and $C / E B P \delta$ genes (Tanaka et al. 1997), which prevented the normal development of adipose tissue.

Early in the adipocyte differentiation program preadipocytes undergo mitotic clonal expansion (Bernlohr et al. 1985; Cornelius et al. 1994; MacDougald and Lane 1995), which appears to be necessary for progression through subsequent steps in the differentiation program (Cornelius et al. 1994; MacDougald and Lane 1995). Thus, treatment with the appropriate hormonal differentiation inducers causes confluent growth-arrested 3T3-L1 preadipocytes to reenter synchronously the cell cycle and undergo two to three rounds of mitosis (Bernlohr et al. 1985; Cornelius et al. 1994). During these mitotic events preadipocytes express high levels of $\mathrm{C} / \mathrm{EBP} \beta / \delta$ /Cao et al. 1991; Yeh et al. 1995). These factors have been shown to activate transcriptionally the $C / E B P \alpha$ gene promoter through a C/EBP regulatory element in the proximal 5' flanking region (Christy et al. 1991; Tang et al. 1999). Expression of $\mathrm{C} / \mathrm{EBP} \alpha$ occurs later as the cells exit the cell cycle, begin to express adipocyte genes, and undergo terminal differentiation (Lin et al. 1993; MacDougald and Lane 1995). Because C/EBP $\alpha$ is antimitotic (Umek et al. 1991; Lin et al. 1993; Timchenko et al. 1996, 1997), it is thought that this transcription factor may be responsible for terminating mitotic clonal expansion (MacDou- 
gald and Lane 1995). Once expressed, C/EBP $\alpha$ is believed to autoactivate transcription of its own gene, mediated by the C/EBP regulatory element (Christy et al. 1991; Lin et al. 1993). This action would ensure that adipocyte gene expression is maintained in terminally differentiated adipocytes (MacDougald and Lane 1995).

In this paper we show that although $\mathrm{C} / \mathrm{EBP} \beta$ and $\mathrm{C} / \mathrm{EBP} \delta$ are expressed soon after (within $4 \mathrm{hr}$ ) the induction of adipocyte differentiation, these transcription factors are unable to bind to the $\mathrm{C} / \mathrm{EBP}$ regulatory element in the $\mathrm{C} / \mathrm{EBP} \alpha$ promoter. However, as the preadipocytes enter $S$ phase at the inception of mitotic clonal expansion, $\mathrm{C} / \mathrm{EBP} \beta / \delta$ begin to acquire the capacity to bind to the C/EBP regulatory element and concomitantly become centromere associated. Upon activation of the $\mathrm{C} / \mathrm{EBP} \alpha$ gene, $\mathrm{C} / \mathrm{EBP} \alpha$ becomes centromere associated and mitiotic clonal expansion ceases.

\section{Results}

Delayed acquisition of DNA-binding function by $C / E B P \beta / \delta$

During differentiation of 3T3-L1 preadipocytes C/EBP $\beta / \delta$ transcriptionally activate the $C / E B P \alpha$ gene through a
C/EBP-binding site in the promoter (see above). Kinetic analysis, however, revealed an unexpectedly long delay between expression of $\mathrm{C} / \mathrm{EBP} \beta / \delta$ and the expression of $\mathrm{C} / \mathrm{EBP} \alpha$. Immunoblots of cell extracts of 3T3-L1 preadipocytes (Fig. 1A) showed that expression of $\mathrm{C} / \mathrm{EBP} \beta / \delta$ occurs rapidly after induction of differentiation, maximal levels being achieved within $4 \mathrm{hr}$ and then maintained for $\sim 48 \mathrm{hr}$. C/EBP $\beta / \delta$ then begin to decline (results not shown). Given that $\mathrm{C} / \mathrm{EBP} \beta / \delta$ are known to be transcriptional activators of the $C / E B P \alpha$ gene, a lag of $\sim 30 \mathrm{hr}$ before expression of $\mathrm{C} / \mathrm{EBP} \alpha$ seemed surprisingly long (Fig. 1A). Once $\mathrm{C} / \mathrm{EBP} \alpha$ was expressed, expression of the 422/aP2 gene occurred almost immediately, a typical adipocyte gene known to be transactivated by $\mathrm{C} / \mathrm{EBP} \alpha$ (Christy et al. 1989; Cheneval et al. 1991) (Fig. 1A). It should be noted that the the kinetics of expression of $\mathrm{C} / \mathrm{EBP} \alpha \mathrm{mRNA}$ closely correlates with the expression of $\mathrm{C} / \mathrm{EBP} \alpha$ protein (results not shown).

In view of the long lag between expression of $\mathrm{C} / \mathrm{EBP} \beta / \delta$ and expression of $\mathrm{C} / \mathrm{EBP} \alpha$, the possibility was considered that translocation of $\mathrm{C} / \mathrm{EBP} \beta / \delta$ into the nucleus might be ratelimiting. Therefore, the intracellular localization of $\mathrm{C} / \mathrm{EBP} \beta / \delta$ was assessed, both by cell fractionation and by in situ immunofluorescence, at
A

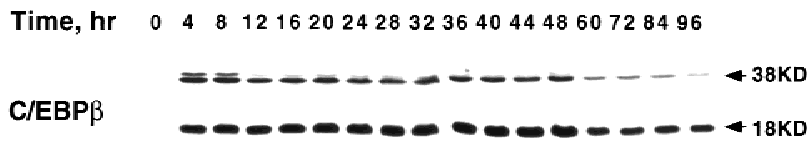

C/EBP $\delta$

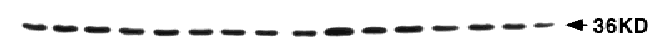

$\mathrm{C} / \mathrm{EBP} \alpha$

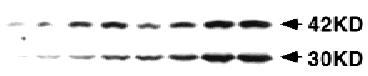

$422 / a P_{2}$
B

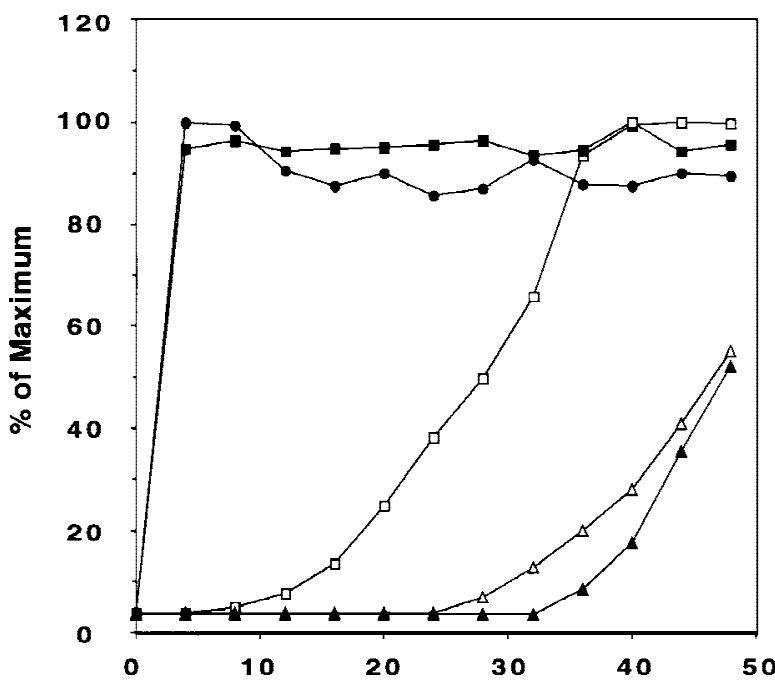

Hours After Induction of Differentiation

Figure 1. Expression of C/EBPs and 422/aP2 during differentiation of 3T3-L1 preadipocytes. (A) Day 0 postconfluent 3T3-L1 preadipocytes were induced to differentiate into adipocytes using the standard differentiation protocol. At different times after induction of differentiation, cell lysates were subjected to SDS-PAGE and Western blotting with antibodies directed against C/EBP $\beta, \mathrm{C} / \mathrm{EBP} \delta$, and $\mathrm{C} / \mathrm{EBP} \alpha$ and $422 / \mathrm{aP} 2$. It should be noted that $\mathrm{C} / \mathrm{EBP} \beta$ and $\mathrm{C} / \mathrm{EBP} \alpha$ each have two isoforms translated from the same mRNA. $(B)$ The results of the Western blots (shown in $A$ ) and DNA-binding acitivities for C/EBP $\beta / \delta$ and C/EBP $\alpha$ shown in Fig. 3D,E, respectively) were quantitated and the results plotted. The binding activities of C/EBP $\beta / \delta$ and C/EBP $\alpha$ in nuclear extracts were assessed by EMSA using an oligonucleotide probe corresponding to the C/EBP regulatory element in the promoter of the C/EBP $\alpha$ gene. Results for $\mathrm{C} / \mathrm{EBP} \beta / \delta$ protein and $\mathrm{C} / \mathrm{EBP} \beta / \delta \mathrm{DNA}$-binding activity are expressed as percent of maximal expression. Results for C/EBP $\alpha \mathrm{DNA}$ binding activity and $422 / \mathrm{aP} 2$ protein, which do not achieve their maxima until much later (> $72 \mathrm{hr}$ ) are expressed as percent of their half-maximal values. The amount of binding activity for $\mathrm{C} / \mathrm{EBP} \beta / \delta$ is based on the amount of label remaining in the EMSA bands attributable to $\mathrm{C} / \mathrm{EBP} \beta / \delta$ after removing $\mathrm{C} / \mathrm{EBP} \alpha$ by supershifting with anti-C/EBP $\alpha$ antibody (data from Fig. $3 \mathrm{E}$ ). Also, the amount of binding activity due to $\mathrm{C} / \mathrm{EBP} \alpha$ is based on the the amount of label remaining in the EMSA bands due to $\mathrm{C} / \mathrm{EBP} \alpha$ after removing $\mathrm{C} / \mathrm{EBP} \beta$ and $\mathrm{C} / \mathrm{EBP} \alpha$ by supershiting with anti-C/EBP $\beta / \delta$ antibodies (data from Fig. $3 \mathrm{D}) .(\mathbf{)}) / \mathrm{EBP} \beta$ protein; $(\mathbf{\square}) \mathrm{C} / \mathrm{EBP} \delta$ protein; $(\square)$ DNA-binding acitivity of $\mathrm{C} / \mathrm{EBP} \beta / \delta_{;}(\triangle) \mathrm{DNA}$-binding acitivity of $\mathrm{C} / \mathrm{EBP} \alpha ;(\mathbf{\Delta}) 422 / \mathrm{aP} 2$ protein. 
various times after the induction of differentiation. As shown in Figure $2 \mathrm{~A}$, virtually all $\mathrm{C} / \mathrm{EBP} \beta / \delta$ was nuclear within $4 \mathrm{hr}$ (and remained nuclear for $24 \mathrm{hr}$ ) after induction. Similar results were obtained with intact preadipocytes by in situ immunostaining with antibody against $\mathrm{C} / \mathrm{EBP} \beta / \delta$. As shown in Figure $2 \mathrm{~B}$ virtually all $\mathrm{C} / \mathrm{EBP} \beta$ immunofluorescence was localized to the nuclei from 4 to $24 \mathrm{hr}$; similar results were obtained for C/EBPS (results not shown). It can be concluded that the reason for the delay in acquiring DNA-binding activity by $\mathrm{C} / \mathrm{EBP} \beta / \delta$ in nuclear extracts is not a result of a lag in the translocating these transcription factors into the nucleus.

To ascertain whether there is a lag in the acquisition of intrinsic DNA-binding activity by $\mathrm{C} / \mathrm{EBP} \beta / \delta$, gel shift assays were performed. An oligonucleotide probe corresponding to the C/EBP-binding site in the $C / E B P \alpha$ gene promoter was used along with nuclear extracts from

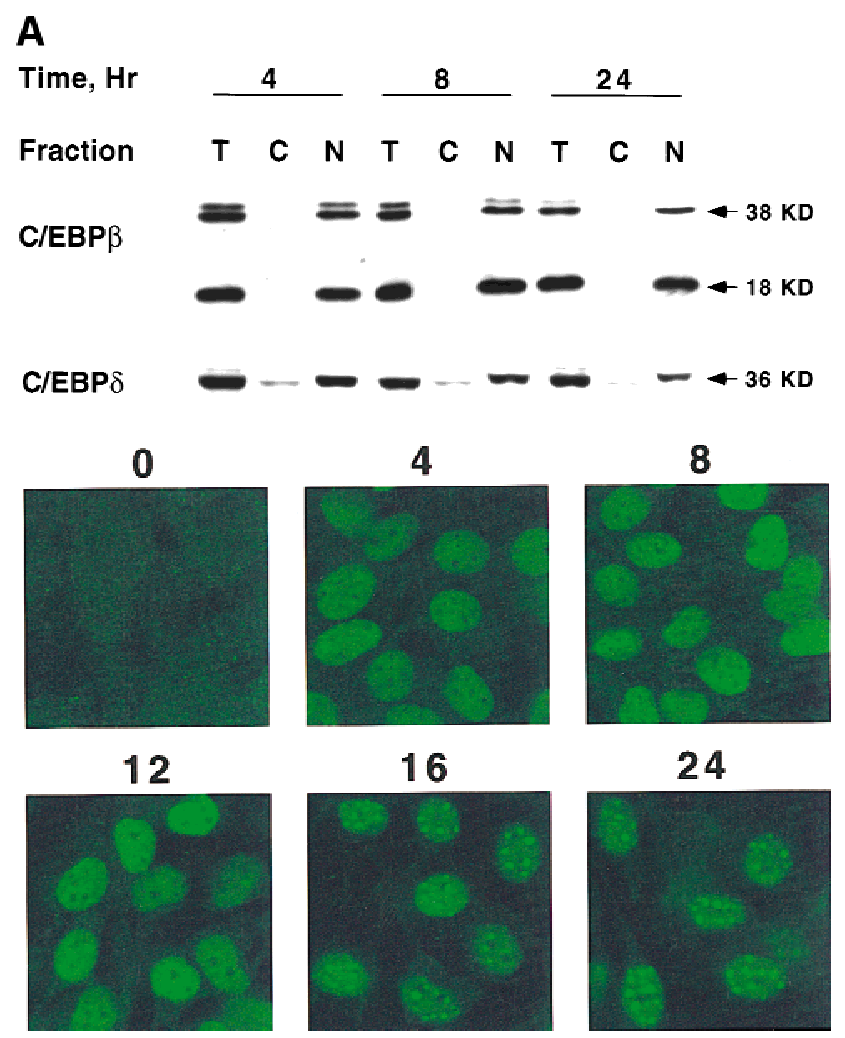

Figure 2. Intracellular localization of $\mathrm{C} / \mathrm{EBP} \beta / \delta$ early in the differentiation program. (A) At 4, 8, and $24 \mathrm{hr}$ after induction of differentiation 3T3-L1 preadipocytes were lysed and resolved into nuclear and cytoplasmic fractions. The total lysate, cytoplasmic, and nuclear fractions (amounts equivalent to the same number of cells) were subjected to SDS-PAGE, then Western blotted with antibodies against C/EBP $\beta / \delta$. $(T)$ Total cell lysate; (C) cytoplasmic fraction; (N) nuclear fraction. (B) 3T3-L1 preadipocytes on coverslips were induced to differentiate. At time 0 and 4, 8, 12, 16, and $24 \mathrm{hr}$ after induction of differentiation the cell monolayers were fixed and subjected to immunofluorescence staining with antibody to C/EBP $\beta$. preadipocytes isolated every $4 \mathrm{hr}$ (for $48 \mathrm{hr}$ ) after induction of differentiation. As shown in Figure 1A maximal expression of $\mathrm{C} / \mathrm{EBP} \beta / \delta$ occurs within $4 \mathrm{hr}$ after induction and remains high for $48 \mathrm{hr}$. However, DNA-binding activity, which begins to increase between 12 and $16 \mathrm{hr}$, requires more than $30 \mathrm{hr}$ to reach a maximum (Fig. 1B and Fig. 3A). It should be noted that the broadness of DNA-protein bands in the gel shift assays is due to homo- and heterodimer formation among the two isoforms of C/EBP $\beta$ and other C/EBPs (MacDougald et al. 1995). A single C/EBP $\beta$ mRNA is known to give rise to two translation products of 38 and $18 \mathrm{kD}$, which can form homo- and heterodimers between themselves and other C/EBPs (Descombes and Schibler 1991). That these DNA-protein complexes contain $\mathrm{C} / \mathrm{EBP} \beta$ or $\mathrm{C} / \mathrm{EBP} \delta$ is verified by the nearly complete supershift of the complexes with antibodies directed against C/EBP $\beta / \delta$ (Fig. 3, cf. A with B, C, and D). Comparison of the supershifts with antibodies against $\mathrm{C} / \mathrm{EBP} \beta / \delta$ (Fig. 3 cf. $\mathrm{A}, \mathrm{B}$, and $\mathrm{C}$ ) shows that $\mathrm{C} / \mathrm{EBP} \beta$ is dominant, relative to $\mathrm{C} / \mathrm{EBP} \delta$, in nuclear extracts from preadipocytes induced to differentiate for $48 \mathrm{hr}$.

The small amount of 'unshifted' protein-oligonucleotide complexes remaining when antibodies to both $\mathrm{C} / \mathrm{EBP} \beta$ and C/EBPS are used (Fig. 3D) is due primarily to $\mathrm{C} / \mathrm{EBP} \alpha$ homo- and heterodimers, which begin to appear 28-32 hr after induction (Fig. 3D). As with C/EBP $\beta$, a single $\mathrm{C} / \mathrm{EBP} \alpha \mathrm{mRNA}$ is known to give rise to two translation products of 42 and $30 \mathrm{kD}$ (Lin et al. 1993), which can form homo- and heterodimers between themselves and with other C/EBPs (MacDougald et al. 1995). This was confirmed with $\mathrm{C} / \mathrm{EBP} \alpha$ antibody, with which it was shown that the supershifted band (due to $\mathrm{C} / \mathrm{EBP} \alpha$ ) exhibits similar kinetics (Fig. 3E) to that of the residual DNA-protein complexes remaining after removal of $\mathrm{C} / \mathrm{EBP} \beta / \delta$ (Fig. 3D). A graphic presentation of these results is given in Figure 1B. Taken together, these findings indicate that there is a long delay in the acquisition of binding activity by $\mathrm{C} / \mathrm{EBP} \beta / \delta$ and suggest that this is responsible for the long delay in the transcriptional activation of the $C / E B P \alpha$ gene.

The acquisition of binding activity by $\mathrm{C} / \mathrm{EBP} \beta / \delta$, which begins between 12 and $16 \mathrm{hr}$ after induction of differentiation (see Fig. 1B), coincides with entry of the preadipocytes into $S$ phase and the onset of mitotic clonal expansion (Bernlohr et al. 1985). Entry into S phase at this time is evidenced by the onset of phosphorylation of Retinoblastoma (Rb) (Fig. 4A) and of labeled thymidine incorporation into cellular DNA (Fig. 4B), both of which occur between 12 and $16 \mathrm{hr}$ after the induction of differentiation. That the band shift of $\mathrm{Rb}$ to lower mobility at $12-16 \mathrm{hr}$ (Fig. 4A) is due to phosphorylation is indicated by the fact that treatment with alkaline phosphatase caused a shift in mobility to that of the faster moving band (Fig. 4A). These events are known to occur at the $G_{1}-S$ checkpoint (Hatakeyama and Weinberg 1995; Reed 1997). It should be recalled that upon induction of the differentiation program, confluent preadipocytes reenter the cell cycle synchronously and undergo several rounds of mitotic clonal expansion (see 
A

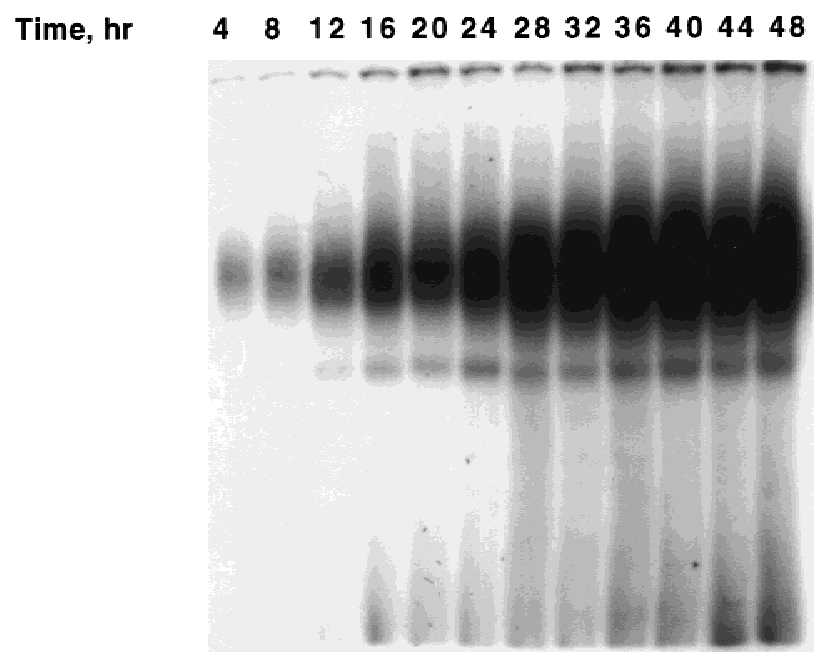

C

Time, hr

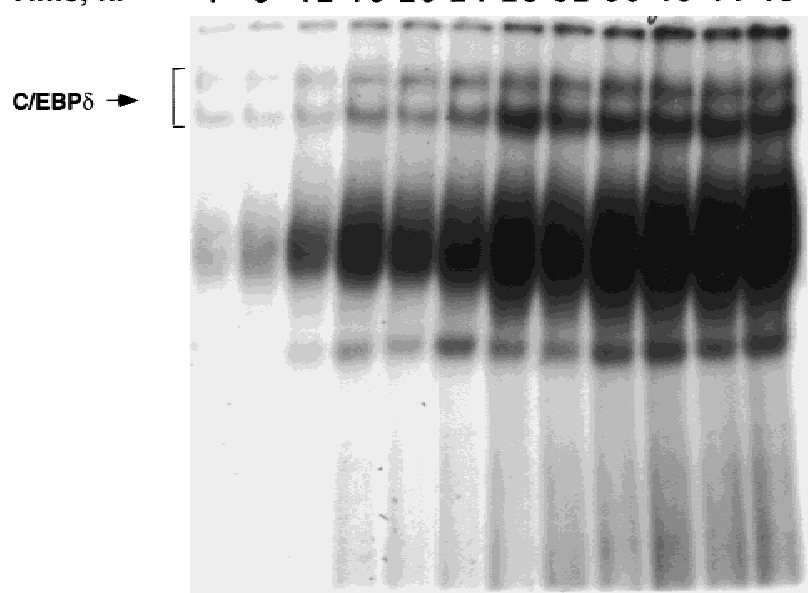

B

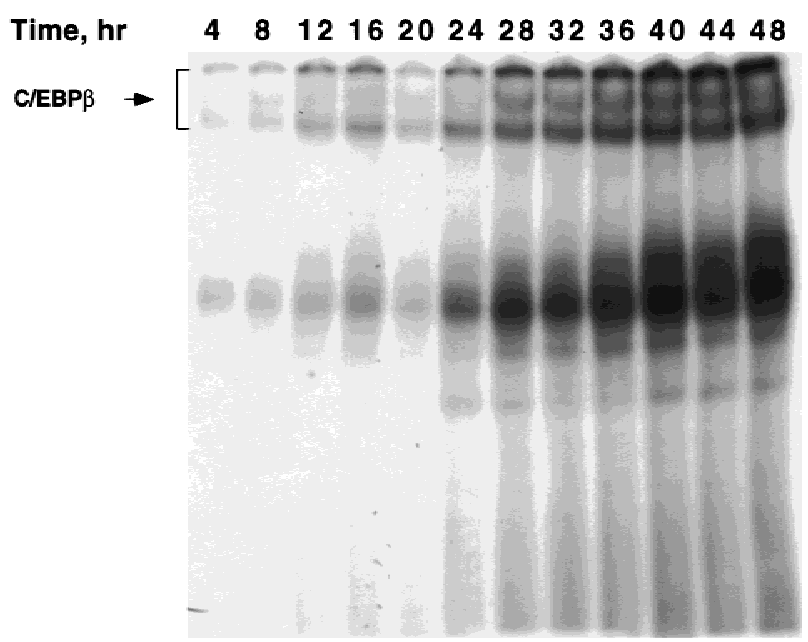

D

Time, hr $\quad 4 \quad 8 \quad 12162024283236404448$

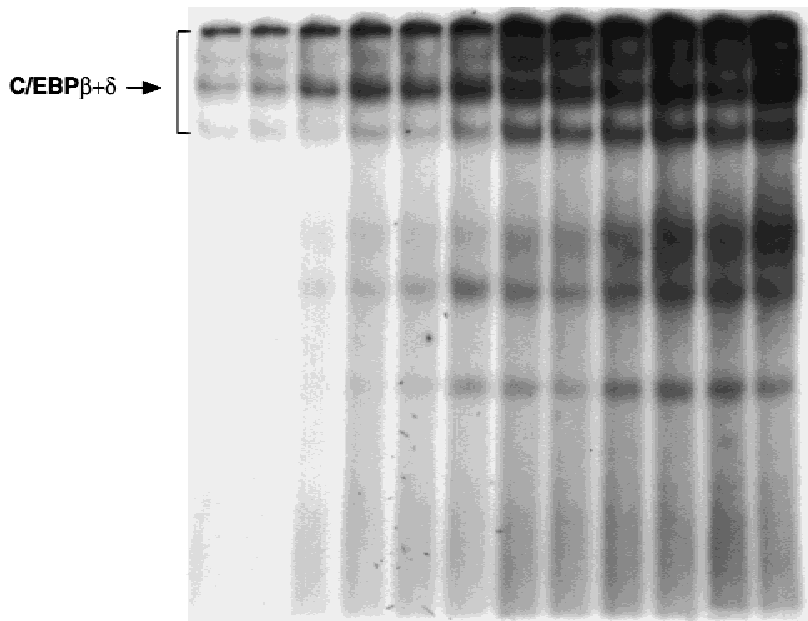

E

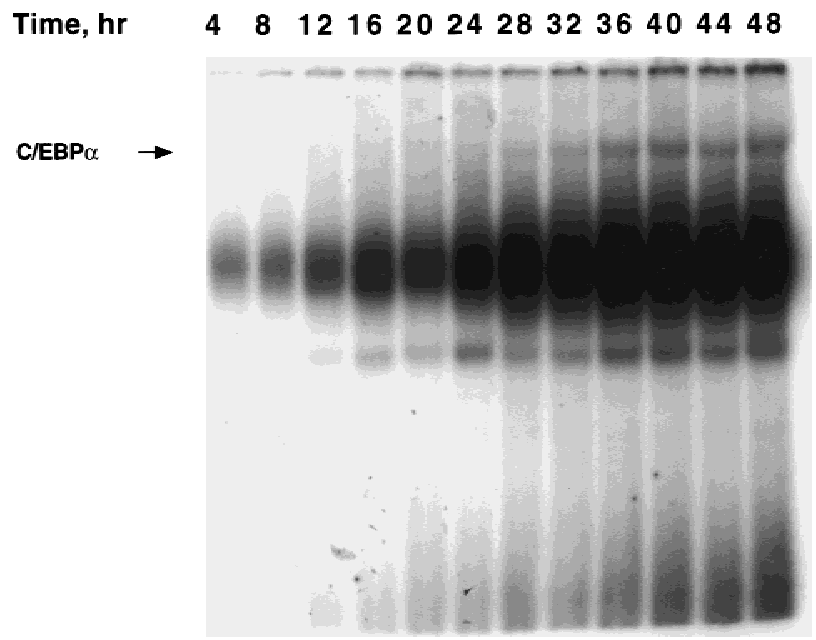

Figure 3. Changes in binding of $\mathrm{C} / \mathrm{EBP} \beta, \mathrm{C} / \mathrm{EBP} \delta$, and $\mathrm{C} / \mathrm{EBP} \alpha$ to the $\mathrm{C} / \mathrm{EBP}$ regulatory element in the $\mathrm{C} / \mathrm{EBP} \alpha$ gene promoter during adipocyte differentiation. EMSA was performed on nuclear extract from 3T3-L1 preadipocytes after induction of differentiation. EMSA was conducted with $10 \mu \mathrm{g}$ of nuclear extract and a labeled oligonucleotide probe corresponding to the C/EBP regulatory element in the $\mathrm{C} / \mathrm{EBP} \alpha$ gene promoter. $(A)$ Day 0 postconfluent 3T3-L1 preadipocytes were induced to differentiation into adipocytes using the standard differentiation protocol. Every $4 \mathrm{hr}$ after induction nuclear extracts were prepared and subjected to EMSA as described in Materials and Methods. Supershift experiments were performed as in $A$ with antibodies directed against: $\mathrm{C} / \mathrm{EBP} \beta(B) ; \mathrm{C} / \mathrm{EBP} \delta(C) ; \mathrm{C} / \mathrm{EBP} \beta$ and $\mathrm{C} / \mathrm{EBP} \delta(D)$; and $\mathrm{C} / \mathrm{EBP} \alpha(E)$. 
$\begin{array}{lllllllllll}\text { Time, } \mathrm{Hr} & 0 & 1 & 2 & 4 & 6 & 8 & 12 & 16 & 20 & 24\end{array}$

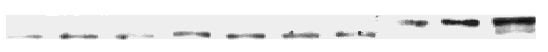

A

$\begin{array}{llllllllllll}\text { Time, Hr } & 4 & 12 & 16 & 20 & 24 & 4 & 12 & 16 & 20 & 24\end{array}$
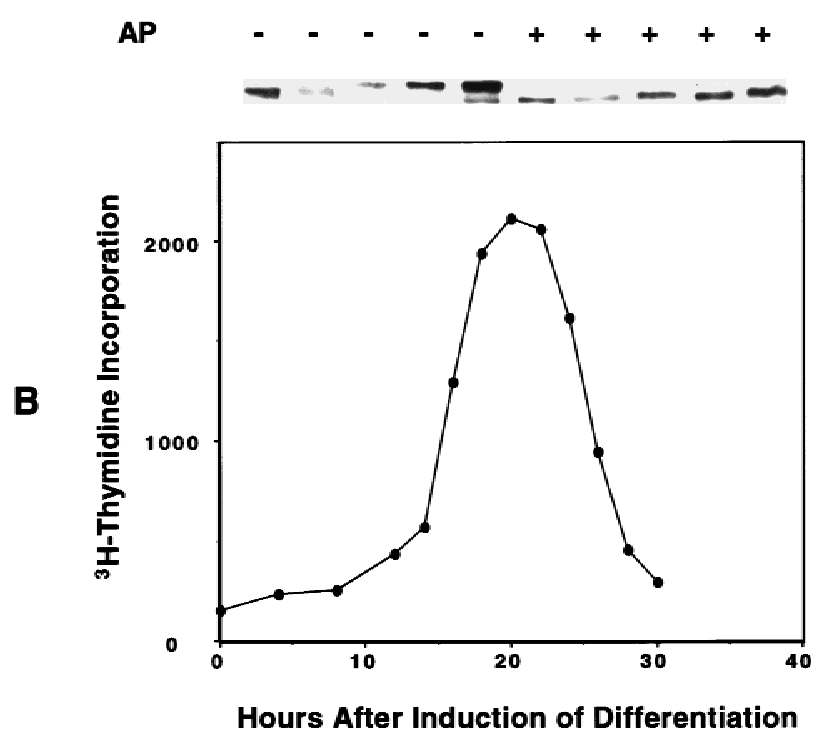

Figure 4. Changes in phosphorylation state of $\mathrm{Rb}$ protein and in $\left[{ }^{3} \mathrm{H}\right]$ thymidine incorporation into DNA during mitotic clonal expansion of preadipocytes induced to differentiate. (A) Day 0 postconfluent 3T3-L1 preadipocytes were subjected to standard differentiation protocol. At the times indicated cell lysates were prepared, subjected to SDS-PAGE, and immunoblotted with antibody against $\mathrm{Rb}$. Incubation of cell lysates with alkaline phosphatase (AP) caused a shift in the mobility of the slow-moving band to that of the faster moving band. $(B)\left[{ }^{3} \mathrm{H}\right]$ Thymidine incorporation into cellular DNA during a 15 -min incubation was determined at 4- or 2-hr intervals for $30 \mathrm{hr}$ after induction of differentiation of 3T3-L1 preadipocytes.

above). A high degree of synchrony of entry into, and exit from, $\mathrm{S}$ phase is indicated by the steepness of the ascending and descending slopes of the labeled thymidine incorporation curve shown in Figure 4.

\section{Centromeric localization of $C / E B P \beta / \delta$ during mitotic clonal expansion}

Immunofluorescent staining with antibody against $\mathrm{C} / \mathrm{EBP} \beta$ shows that $\mathrm{C} / \mathrm{EBP} \beta$ is distributed diffusely within the nuclei of preadipocytes between 4 and $12 \mathrm{hr}$ after the induction of differentiation (see Fig. 2B). However, between 12 and $24 \mathrm{hr}$ the immunofluorescence becomes punctate (Figs. 2B and 5A, top), a pattern that persists throughout the remainder of the cell cycle (see below). A similar immunofluorescence staining pattern occurs with antibody against C/EBPS (results not shown). The shift from diffuse to punctate Immunofluorescence of $C / E B P \beta / \delta$ antibody (see Fig. $2 B$ ) and acquisition of DNA-binding activity (see Fig. 1B) occur concomitantly and correlate well with the phosphorylation of $\mathrm{Rb}$ (see Fig. 4A) and the onset of labeled thymidine incorporation into cellular DNA (see Fig. 4B). Both of the latter phenomena are known to begin at the $G_{1}-S$ checkpoint and to continue during $S$ phase of the cell cycle (Hatakeyama and Weinberg 1995; Reed 1997). These findings suggested that upon acquiring DNA-binding activity, C/EBP $\beta$ becomes associated with 'punctate' nuclear entities. Of interest, these nuclear sites of interaction with $\mathrm{C} / \mathrm{EBP} \beta / \delta$ antibodies appeared to coincide with the bright punctate nuclear sites of DAPI fluorescence, which are evident both before and after induction of differentiation (Fig. 5A, bottom). DAPI is known to interact strongly with the centromeric heterochromatin of mouse chromosomes. Comparison of the localization of DAPI and C/EBP $\beta$ antibody staining by confocal fluorescence imaging revealed that these sites are coincident as evident from their overlapping fluorescences (Fig. 5B). It should be noted that the punctate nature of immunostaining of nuclei with antibody directed against C/EBP $\beta$ has been observed previously in macrophage cell lines (Baer et al. 1998). Although it was not determined that these immunostained sites were centromeres, this seems likely as the same punctate-stained regions were also stained with DAPI.

After a long lag (i.e., $12-16 \mathrm{hr}$ from the time of induction of differentiation) there is a shift from diffuse to punctate nuclear immunofluorescence as preadipocytes enter S phase. Centromeric localization of C/EBP $\beta$ persists throughout the $G_{2}, M$, and cleavage stages of the cell cycle as indicated by the series of images of selected cells $28 \mathrm{hr}$ after induction of differentiation (Fig. 5C). Although centromeric localization of C/EBP $\beta$ was suspected because of its coincidence with the sites of DAPI staining, this was verified with an antibody against centromere protein B (CENP-B), a bonafide centromeric protein (Earnshaw et al. 1989; Masumoto et al. 1989). As shown in Fig. 5D, immunostaining of CENP-B colocalizes with $\mathrm{C} / \mathrm{EBP} \beta$, although CENP-B staining is more focal being restricted to the edges of the centromeres. This is consistent with the fact that CENP-B associates with centromers (Earnshaw et al. 1989; Masumoto et al. 1989). Taken together these results indicate that $\mathrm{C} / \mathrm{EBP} \beta / \delta$ (results not shown) become associated with centromeres at the point in the differentiation program when preadipocytes enter $S$ phase at the onset of mitotic clonal expansion.

As C $/ E B P \beta / \delta$ achieve maximal DNA-binding activity (see Fig. 1B) and the expression of $\mathrm{C} / \mathrm{EBP} \alpha$ is initiated (see Fig. 1A), an association of $\mathrm{C} / \mathrm{EBP} \alpha$ with centromeres begins (Fig. 5E, cf. $24 \mathrm{hr}$ and $48 \mathrm{hr}$ ). At $24 \mathrm{hr}$ before the expression of $\mathrm{C} / \mathrm{EBP} \alpha$ no immunofluorescence is detected, however, by $48 \mathrm{hr}$ when expression of C/EBP $\alpha$ has been initiated a significant percentage $(\sim 40-50 \%)$ of the cells exhibit immunofluorescence with antibody to $\mathrm{C} / \mathrm{EBP} \alpha$. Although the expression of $\mathrm{C} / \mathrm{EBP} \alpha$ does not reach its maximum until $>72 \mathrm{hr}$, immunostaining at times beyond $48 \mathrm{hr}$ after induction of differentiation becomes uninterpretable because of the high levels of IgGadsorbing glycose aminoglycans secreted by and adhering to the cells at that point in the differentiation pro- 

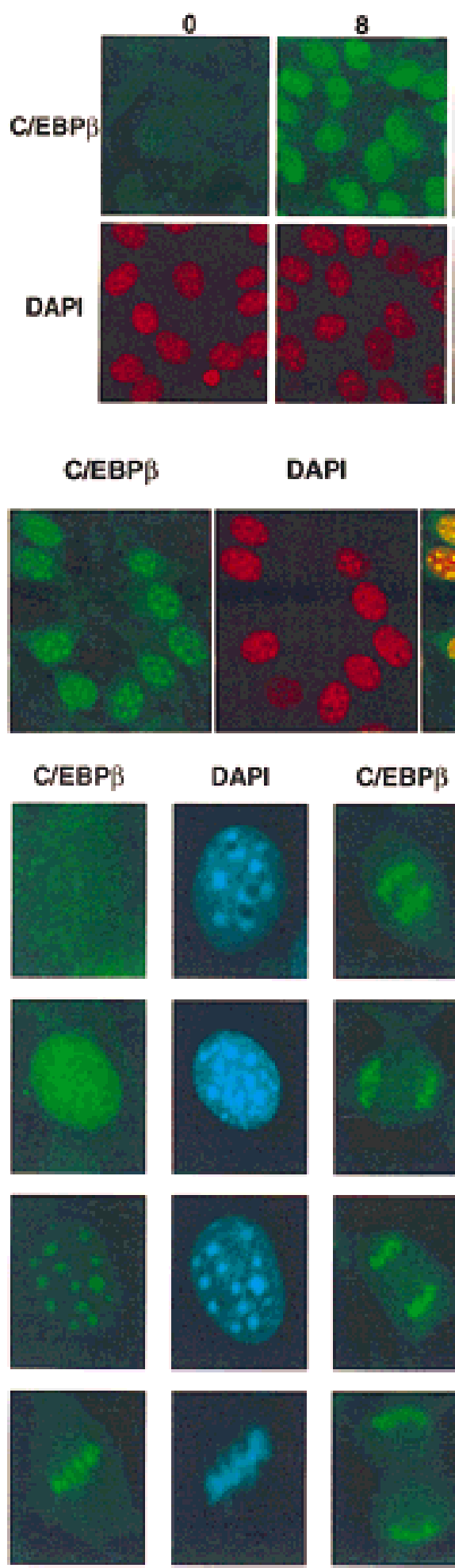

\section{DAPI}

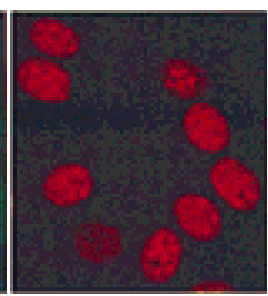

DAPI
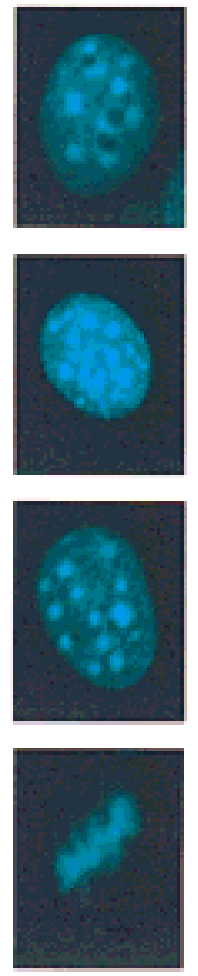
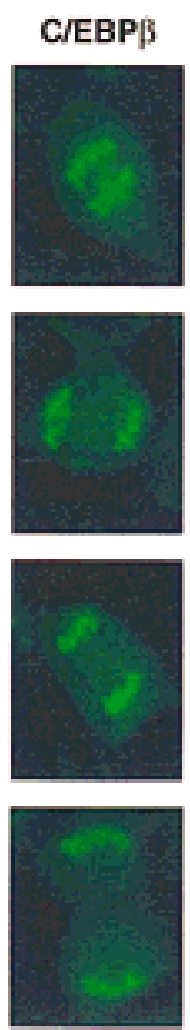

24

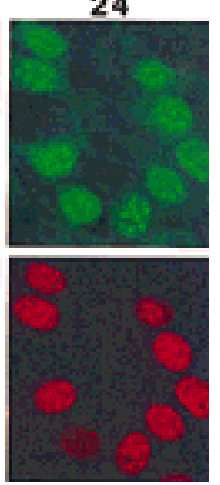

C/EBP $\beta$

DÄPI

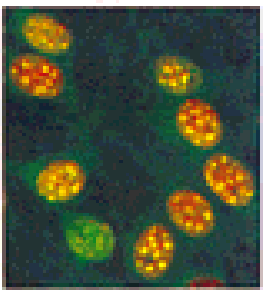

DAPI
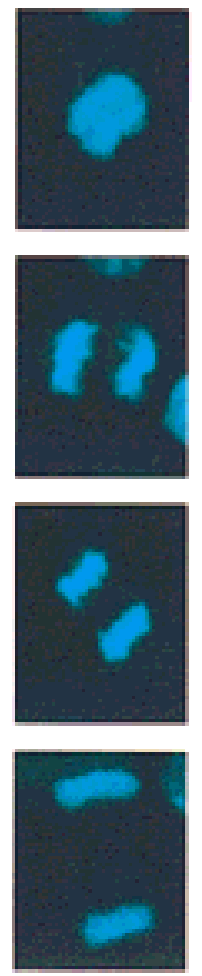
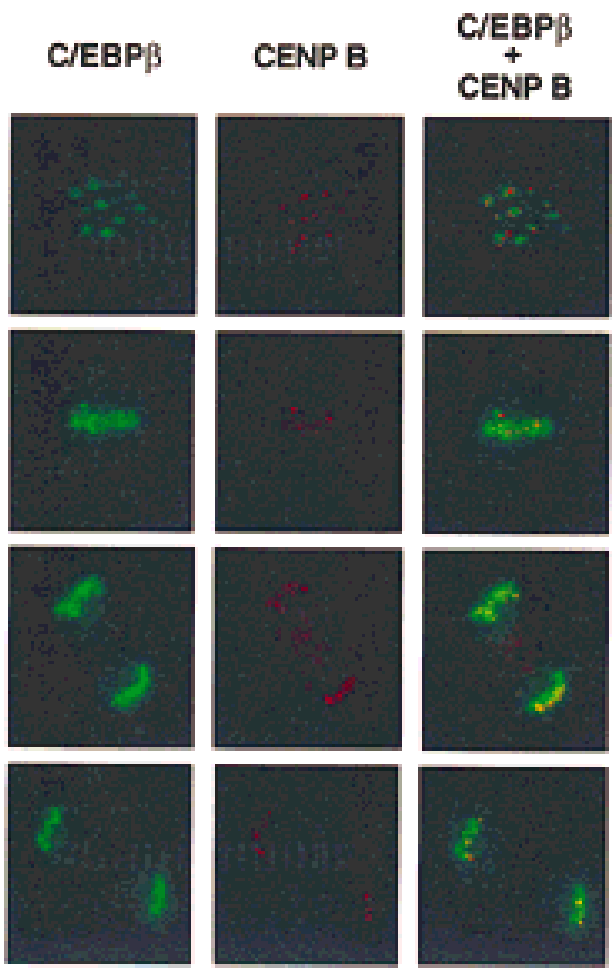

24

48
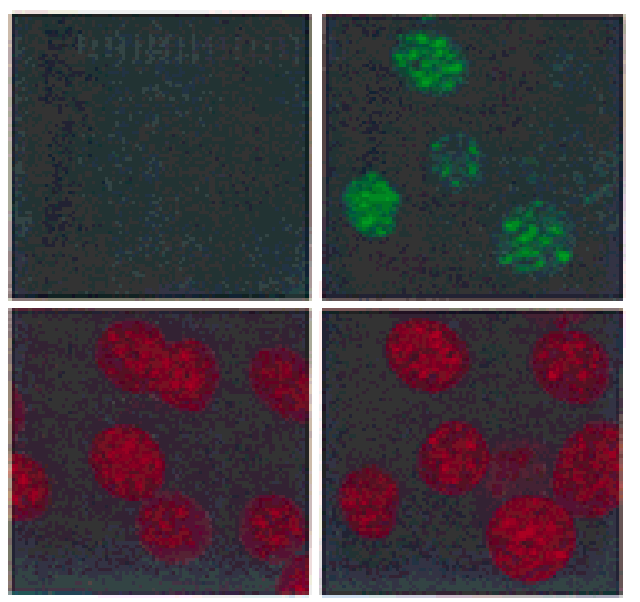

Figure 5. Colocalization of $\mathrm{C} / \mathrm{EBP} \beta, \mathrm{C} / \mathrm{EBP} \alpha$, and CENP-B and DAPI staining during differentiation of 3T3-L1 preadipocytes. 3T3-L1 preadipocytes were induced to differentiate using the standard protocol, fixed, treated with antibodies (and FITC-labeled anti-rabbit IgG), and DAPI at the times indicated. Fluorescence images were obtained by confocal microscopy. $(A$, top $)$ Immunofluorescence with antibody against C/EBP $\beta$ and FITC-labeled anti-rabbit IgG. Similar results were obtained with antibody against C/EBPS (results not shown). (Bottom) Immunofluorescence imaging of the same field as in $A$ with DAPI. (B) Dual fluorescence imaging of C/EBP $\beta$ and DAPI by confocal microscopy of cells $24 \mathrm{hr}$ after induction of differentiation. $(C)$ Fluorescence imaging of 3T3-L1 preadipocytes treated with C/EBP $\beta$ antibody and DAPI during the first round of mitotic clonal expansion. These selected images of preadipocytes at $28 \mathrm{hr}$ after induction of differentiation represent various stages of the cell cycle. $(D)$ Fluorescence imaging of 3T3-L1 preadipocytes treated with antibodies against C/EBP $\beta$ and CENP-B during the first round of mitotic clonal expansion. These selected images of preadipocytes at $28 \mathrm{hr}$ after induction of differentiation represent various stages of the cell cycle. The column on the right represents dual fluorescence images of the two columns of images to the left. $(E)$ Colocalization of immunofluorescence of $\mathrm{C} / \mathrm{EBP} \alpha$ antibody and DAPI in the terminal stages of the differentiation program. 
gram. Centromeric binding of $\mathrm{C} / \mathrm{EBP} \alpha$ begins as 3T3-L1 preadipocytes exit the cell cycle and become growth arrested. Previously, we showed that mitosis ceases by $\sim 72$ hr after induction of differentiation (Bernlohr et al. 1985). In view of the fact that $\mathrm{C} / \mathrm{EBP} \alpha$ is antimitotic (Umek et al. 1991), the question arises, does the interaction of $\mathrm{C} / \mathrm{EBP} \alpha$ with centromeres play a role in terminating mitotic clonal expansion?

\section{Binding of the C/EBPs to centromeric satellite DNA}

It is well-known that the bright fluorescent spots in mouse nuclei stained with DAPI are due to heterochromatic satellite DNA (Miller et al. 1974; Hendrich and Bird 1998). Because the pattern of DAPI fluorescence was virtually identical to that of $\mathrm{C} / \mathrm{EBP} \beta$ (Fig. 5B) and C/EBPS (results not shown) and mouse satellite DNA is located primarily in centromeres (Stephanova et al. 1988; Joseph et al. 1989), the possibility was considered that $\mathrm{C} / \mathrm{EBP} \beta / \delta$ bind to sequences in centromeric satellite DNA. Inspection of the nucleotide sequence of the major species of mouse satellite DNA (Horz and Altenburger 1981) reveals eight repeats of a consensus C/EBP binding site (Fig. 6A). To ascertain whether C/EBP $\beta$ can bind to satellite DNA, electro phoretic mobility shift analysis (EMSA) experiments were performed with $\mathrm{rC} / \mathrm{EBP} \beta$ and a 234-bp segment of the major mouse satellite DNA that contains these consensus sequences. Remarkably, in gel shift experiments $\mathrm{rC} / \mathrm{EBP} \beta$ gives rise to about eight DNA-protein complexes with mouse satellite DNA (Fig. $6 \mathrm{~B})$. As the concentration of $\mathrm{rC} / \mathrm{EBP} \beta$ is increased, the fraction of lower mobility complexes increases, presumably reflecting increasing numbers of molecules of $\mathrm{rC} /$ EBP $\beta$ s bound per molecule of satellite DNA. Moreover, unlabeled competitor monomeric oligonucleotide /corresponding to the $\mathrm{C} / \mathrm{EBP}$-binding site in the $\mathrm{C} / \mathrm{EBP} \alpha$ gene promoter) causes a shift in the distribution of mobilities back to complexes of higher mobility. That all of the protein-DNA complexes contain $\mathrm{rC} / \mathrm{EBP} \beta$ is indicated by the ability of anti-C/EBP $\beta$ antibody to supershift all complexes (Fig. 6B). These findings provide convincing evidence that $\mathrm{rC} / \mathrm{EBP} \beta$ binds to satellite DNA. Gel shift

\section{A}

1. GGACCTGGAATATGGCGAGAAAACTGAA

1
1

2. AATCACGgAaAATGAGAAATACACACTTTA 29

3. GGACGTGAAATATGGCGAGGAAAACTGAA 59

87

4. AAAGGTGGAAAAITTAGAAATGTCCACTGTA 88

5. GGACGTGGAATATGGCAAGAAAACTGAA 119

6. AATCATGGAAAATGAGAAACATCCACTTGA $147 \quad 176$

7. CGACTIGAAAAATGACGAAATCACTAAA 177204

8. AAACGTGAAAAATGAGAAATGCACACTGAA 205

234

C/EBP Binding Site $T_{G}^{T}$ NNGNAAT $_{G}$

\section{C}

Nuclear Extract, Hr $\begin{array}{lllllllll}4 & 24 & 4 & 24 & 4 & 24 & 4 & 24\end{array}$

Antibody

Compititor
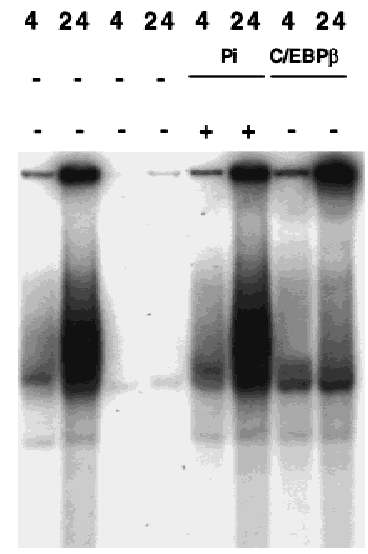

B

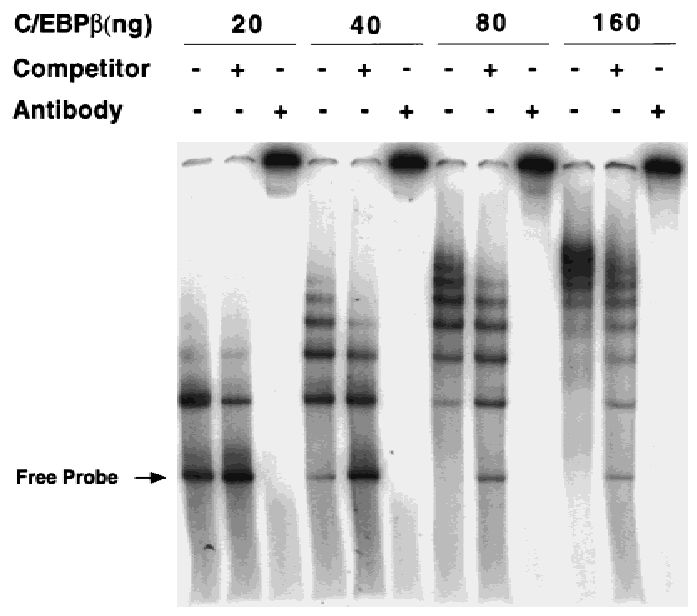

Figure 6. Association of mouse satellite DNA with $\mathrm{rC} / \mathrm{EBP} \beta$ or $\mathrm{C} / \mathrm{EBP} \delta$ in nuclear extract from 3T3-L1 preadipocytes induced to differentiate. $(A)$ Nucleotide sequence of $234 \mathrm{bp}$ of the major mouse satellite DNA. The underlined repetitive sequences represent probable C/EBP-binding sites based on their similarity to the consensus sequence for C/EBP-binding sites (shown at bottom) in numerous gene promoters. (B) EMSA with $\mathrm{rC} / \mathrm{EBP} \beta$ and a 234-bp oligonucleotide probe corresponding to the major mouse satellite DNA. The unlabeled competitor oligonucleotide corresponds to the $\mathrm{C} / \mathrm{EBP}$ regulatory element in the $\mathrm{C} / \mathrm{EBP} \alpha$ gene promoter. Similar results (not shown) were obtained with a competitor oligonucleotide corresponding to sequence 7 in $A$. $(C)$ Nuclear extracts from 3T3-L1 preadipocytes 4 or $24 \mathrm{hr}$ after induction of differentiation were subjected to EMSA with a labeled oligonucleotide probe corresponding to C/EBP-binding site (sequence 7 in the major mouse satellite DNA; see $A$; Materials and Methods). Supershift experiments were performed with preimmune serum (Pi) or anti-serum to $\mathrm{C} / \mathrm{EBP} \beta$. 
experiments were also performed with $\mathrm{C} / \mathrm{EBP} \beta$ in nuclear extracts from 3T3-L1 preadipocytes to verify that 'active' $\mathrm{C} / \mathrm{EBP} \beta$ in preadipocytes induced to differentiate for $24 \mathrm{hr}$ (a point at which C/EBP $\beta$ has acquired DNA-binding activity; see Fig. 1B), binds to a satellite DNA C/EBP-binding site probe /corresponding to sequence 7 in Figure 6A). As shown in Figure 6C, C/EBP in 24-hr nuclear extract binds, whereas that in 4-hr nuclear extract (from cells in which C/EBP $\beta$ has not yet acquired DNA-binding activity; see Fig. 1B/ does not. Supershift experiments with antibody to C/EBP $\beta$ verified that practically all of the DNA-protein complexes formed with the 24-hr nuclear extract are due to C/EBP $\beta$. Similar results were obtained with C/EBP $\alpha$ in nuclear extracts from fully differentiated cells (results not shown). Taken together these results provide compelling evidence that the C/EBPs interact with centromeres by binding to centromeric satellite DNA.

\section{Discussion}

Induction of differentiation of 3T3-L1 preadipocytes sets into motion a cascade of events beginning with the expression of C/EBP $\beta$ and C/EBPS (Fig. 1A,B) (Cao et al. 1991; Yeh et al. 1995), these factors being transcriptional activators of the $\mathrm{C} / \mathrm{EBP} \alpha$ gene (Tang et al. 1999). There is a delay, however, of nearly $30 \mathrm{hr}$ before $C / E B P \alpha$ gene is expressed (Fig. 1). Expression of $\mathrm{C} / \mathrm{EBP} \alpha$ is followed almost immediately by transcriptional activation of the adipocyte genes, such as the $a P 2$ gene (Fig. 1), which are transcriptionally activated by $\mathrm{C} / \mathrm{EBP} \alpha$ (Christy et al. 1989; Cheneval et al. 1991). C/EBP $\alpha$ serves as a plieotropic transactivator of numerous adipocyte genes that are coordinately expressed and contribute to the terminally differentiated phenotype (Christy et al. 1989, 1991; Herrera et al. 1989; Kaestner et al. 1990; Cheneval et al. 1991; Hwang et al. 1996).

The results presented in this paper indicate that the delayed expression of the $C / E B P \alpha$ gene (Fig. 1A) is due to the very slow acquisition of $\mathrm{C} / \mathrm{EBP} \beta / \delta$-binding activity (Figs. 1B and 3), hence delayed transcriptional activation of the $\mathrm{C} / \mathrm{EBP} \alpha$ gene. A question arises as to how $\mathrm{C} / \mathrm{EBP} \beta / \delta$ acquire DNA-binding activity. Although the molecular basis for this acquisition of binding activity is not yet known, preliminary findings suggest that C/EBP $\beta$ undergoes critical phosphorylation events concomitant with acquisition of DNA-binding activity. As shown in Figure 7 exposure of nuclear extracts from 3T3L1 preadipocytes (induced to differentiate for 4 or $24 \mathrm{hr}$ ) to alkaline phosphatase in vitro markedly (by $70-80 \%$ ) reduced the DNA-binding activity of C/EBP 3 . Although this finding suggests that acquisition of binding activity during mitotic clonal expansion involves phosphorylation of $\mathrm{C} / \mathrm{EBP} \beta$, to prove this point definitively it will be necessary to identify the sites of phosphorylation responsible for the acquisition of DNA-binding activity in the context of clonal expansion. This will be a major undertaking, as C/EBP $\beta$ appears to be phosphorylated at multiple sites. Thus, C/EBP $\beta$ exhibits a complex pattern of apparent phosphorylated species on two-dimensional

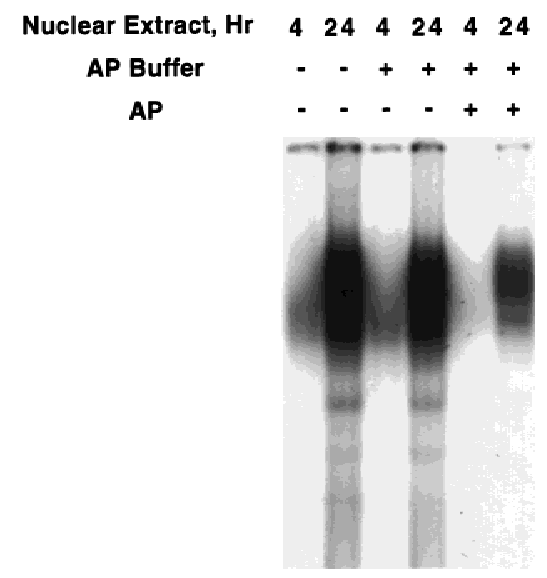

Figure 7. Effect of phosphatase treatment on DNA-binding activity of nuclear extract from "induced" 3T3-L1 preadipocytes. Nuclear extract (10 $\mathrm{\mu g}$ of protein), prepared from 3T3-L1 preadipocytes after induction of differentiation for 4 or $24 \mathrm{hr}$, was incubated for $30 \mathrm{~min}$ at $37^{\circ} \mathrm{C}$ in an incubation mixture containing $50 \mathrm{~mm}$ Tris- $\mathrm{HCl}(\mathrm{pH} 8.5)$ and $0.1 \mathrm{~mm}$ EDTA in the absence or presence of 80 units of Escherichia coli alkaline phosphatase in a total volume of $40 \mu \mathrm{l}$. EMSA was then performed with a "fill-in" ${ }^{32} \mathrm{P}$-labeled oligonucleotide probe corresponding to the $\mathrm{C} / \mathrm{EBP}$ regulatory element in the $\mathrm{C} / \mathrm{EBP} \alpha$ gene promoter.

isoelectric focusing SDS-polyacrylamide gels (Q.-Q. Tang and M.D. Lane, unpubl.). In the isoelectric focusing dimension, we estimate that there are six to eight species of $\mathrm{C} / \mathrm{EBP} \beta / \mathrm{LAP}$ (the $38-\mathrm{kD}$ isoform of $\mathrm{C} / \mathrm{EBP} \beta$ ) presumably reflecting different extents or combinations of phosphorylation. Other evidence consistent with the view that phosphorylation may play a role in the acquisition of the DNA-binding activity by $C / E B P \beta$ was reported by Williams et al. (1995). Thus, C/EBP $\beta$ possesses two regulatory regions. Mutations in a serine-rich sequence in one of these regions, which contains several presumptive protein kinase target sites, leads to increased DNA-binding activity by $\mathrm{C} / \mathrm{EBP} \beta$. It was suggested that before phosphorylation, C/EBP $\beta$ assumes a tightly folded conformation in which the DNA-binding domain is obscured by interaction with the regulatory domain. Phosphorylation of the regulatory domain would be expected to disrupt this interaction rendering the binding domain accessible for binding to DNA (Williams et al. 1995). This hypothesis is consistent with the finding that C/EBP $\beta$ undergoes phosphorylation concomitant with the acquisition of DNA-binding activity and the initiation of mitotic clonal expansion during differentiation of 3T3-L1 preadipocytes. Studies are under way to test this hypothesis.

We suggest that the delayed acquisition of DNA-binding activity by $\mathrm{C} / \mathrm{EBP} \beta / \delta$ (Fig. $1 \mathrm{~B}$ ) forestalls the expression of $\mathrm{C} / \mathrm{EBP} \alpha$ to a point later in the differentiation program that does not interfere with mitotic clonal expansion. Because $\mathrm{C} / \mathrm{EBP} \alpha$ is antimitotic, this is an important consideration as mitotic clonal expansion is required for the events of terminal differentiation (Cornelius et al. 1994; MacDougald and Lane 1995). It has been suggested that DNA replication and the accompa- 
nying remodeling of chromatin during mitotic clonal expansion may allow access of cis-acting elements to trans-acting factors that activate (or derepress) transcription of genes critical for completion of the differentiation program (MacDougald and Lane 1995). That the delayed acquisition of DNA-binding activity by $\mathrm{C} / \mathrm{EBP} \beta / \delta \mathrm{dem}$ onstrated in vitro (by EMSA) also occurs in intact 3T3-L1 preadipocytes is indicated by the delayed interaction of $\mathrm{C} / \mathrm{EBP} \beta / \delta$ with centromeres (Fig. $2 \mathrm{~B}$ ). This interaction is due to the binding of $C / E B P \beta / \delta$ (and later $C / E B P \alpha$ ) to centromeric satellite DNA (Fig. 5B). It should be emphasized that during differentiation, the acquisition of binding activity by $\mathrm{C} / \mathrm{EBP} \beta / \delta$ (in nuclear extracts as measured by EMSA) to probes corresponding to the C/EBPbinding sites in mouse satellite DNA (Fig. $6 \mathrm{C}$ ) and the $C / E B P \alpha$ gene promoter (Fig. 1B) occur at the same rate. Were $\mathrm{C} / \mathrm{EBP} \beta / \delta$ to be 'activated' earlier, transcriptional activation of the $C / E B P \alpha$ gene would be expected to cause premature expression of $\mathrm{C} / \mathrm{EBP} \alpha$. As $\mathrm{C} / \mathrm{EBP} \alpha$ is antimitotic, its expression at this point would be expected to block mitotic clonal expansion and thus, subsequent steps in the differentiation program. Thus, delayed acquisition of DNA-binding activity by $\mathrm{C} / \mathrm{EBP} \beta$ and C/EBP $\delta$ would circumvent this problem. It should be noted that Trautwein et al. (1994) observed that phosphorylation of C/EBP $\beta$ in vitro at Ser- 240 by protein kinases $\mathrm{A}$ or $\mathrm{C}$ decreased DNA-binding activity. However, phosphorylation of Ser-240 was not increased by activation of protein kinases $\mathrm{A}$ or $\mathrm{C}$ in an ex vivo context.

The interaction of C/EBP $\beta, C / E B P \delta$, and C/EBP $\alpha$ with centromeres may have functional significance in the control of mitotic clonal expansion, a prerequisite for subsequent adipocyte differentiation. These interactions occur at different points in the differentiation program. $\mathrm{C} / \mathrm{EBP} \beta / \delta$ become associated with centromeres as preadipocytes enter $S$ phase at the inception of mitotic clonal expansion and maintain this association through about two to three rounds of mitosis. Later in the program, as cellular levels of $\mathrm{C} / \mathrm{EBP} \beta / \delta$ begin to decline, expression of $\mathrm{C} / \mathrm{EBP} \alpha$ reaches a maximum and mitosis ceases, consistent with the fact that $\mathrm{C} / \mathrm{EBP} \alpha$ is antimitotic (Umek et al. 1991; Lin et al. 1993; Timchenko et al.

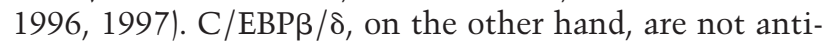
mitotic. In view of the sequential timing of expression of the C/EBPs and their concurrent acquisition of function and interaction with centromeres, we suggest that binding of $C / E B P \beta / \delta$ to centromeres may participate in the regulation of mitotic clonal expansion. Conceivably, binding of $\mathrm{C} / \mathrm{EBP} \beta / \delta$ to centromeres early in the program might activate progression through the $\mathrm{G}_{1}-\mathrm{S}$ checkpoint, whereas the interaction of $\mathrm{C} / \mathrm{EBP} \alpha$ with centromeres, which occurs much later, may cause preadipocytes to exit the cell cycle. Studies are underway to test these hypotheses.

\section{Materials and methods}

Cell culture and induction of differentiation

3T3-L1 preadipocytes were propagated and maintained in DMEM containing $10 \%$ (vol/vol) calf serum as described (Stu- dent et al. 1980). To induce differentiation, 2-day postconfluent preadipocytes (designated day 0) were fed DMEM containing $10 \%$ (vol/vol) fetal bovine serum (FBS), $1 \mu \mathrm{g} / \mathrm{ml}$ insulin, $1 \mu \mathrm{M}$ dexamethasone, and $0.5 \mathrm{~mm}$ 3-isobutyl-1-methylxanthine (MIX) until day 2. Cells were then fed DMEM supplemented with 10\% FBS and $1 \mu \mathrm{g} / \mathrm{ml}$ insulin for 2 days, after which they were fed every other day with DMEM containing 10\% FBS. Adipocyte gene expression and acquisition of the adipocyte phenotype begins on day 3 and is maximal by day 8 .

\section{EMSA}

Nuclei were isolated and nuclear extracts prepared using $1 \times$ NUN buffer (Lavery and Schibler 1993) containing $0.3 \mathrm{M} \mathrm{NaCl}$, $1 \mathrm{M}$ urea, $1 \%$ Nonidet P-40, $25 \mathrm{~mm}$ HEPES ( $\mathrm{pH} 7.9$ ), and $1 \mathrm{~mm}$ DTT. Protein concentration was determined by the Bradford method (Bio-Rad). EMSA was performed essentially as described (MacDougald et al. 1994, 1995) with the following modifications. Reaction mixtures containing $\sim 0.25 \mathrm{ng}$ of the appropriate ${ }^{32} \mathrm{P}$-labeled oligonucleotide probe (2.5 ng for the 234-bp satellite DNA), $2 \mu \mathrm{g}$ of poly [d(I-C)], and $10 \mu \mathrm{g}$ of nuclear extract protein in $30 \mu \mathrm{l}$ of buffer (10 mM HEPES, $0.1 \mathrm{~mm}$ EDTA, 5\% glycerol, $100 \mathrm{~mm} \mathrm{NaCl}, 0.3 \mathrm{~m}$ urea, $0.3 \% \mathrm{NP}-40$ ) were incubated on ice for $15 \mathrm{~min}$, at room temperature for $15 \mathrm{~min}$, and then were separated electrophoretically on $5 \%$ polyacrylamide gels $0.5 \times$ TBE [44.5 mM Tris, $44.5 \mathrm{~mm}$ boric acid, 1 mM EDTA (pH 8.3)]. For competition experiments, a 100-fold excess of unlabeled competitor oligonucleotide was added to reaction mixtures before the addition of labeled probe. For supershift experiments, 1 $\mu \mathrm{l}$ of antiserum ( $5 \mu \mathrm{g}$ of IgG protein) was added to the reaction mixture before the addition of labeled probe. Recombinant C/EBP $\beta$ was obtained from Steven McKnight (University of Texas Southwestern Medical Center, Dallas). The labeled oligonucleotide probes included double-stranded oligonucleotides corresponding to (1) the C/EBP regulatory element in the C/EBP $\alpha$ promoter, $(-191)$ GCGTTGCGCCACGATCTCTC $(-172)$; and (2) one of the C/EBP-binding sites in mouse satellite DNA, (182) TGAAAAATGACGAAATCACTA(202).

The 234-bp mouse satellite DNA probe was prepared by cutting pBR 322-M.Sat.4 (from Wolf Stratling, University-Krankenhaus Eppendorf, Hamburg, Germany) with BamHI.

\section{Western blotting and phosphatase treatment}

To follow changes in the level of $\mathrm{C} / \mathrm{EBP} \alpha, \mathrm{C} / \mathrm{EBP} \beta$, and $\mathrm{C} / \mathrm{EBP} \delta$, $\mathrm{Rb}$ and $422 / \mathrm{aP} 2$ proteins after induction of differentiation, 2-day postconfluent (day 0) 3T3-L1 preadipocytes were treated with MDI in $10 \%$ FBS as described as above. At various times thereafter, cell monolayers (6-cm dishes) were washed once with cold phosphate-buffered saline (PBS) ( $\mathrm{pH}$ 7.4) and then scraped into lysis buffer containing $1 \%$ SDS and $60 \mathrm{~mm}$ Tris$\mathrm{HCl}$ (pH 6.8). Lysates were heated at $100^{\circ} \mathrm{C}$ for $10 \mathrm{~min}$, clarified by centrifugation, and then equal amounts of protein were subjected to SDS-PAGE and immunoblotted with antibodies to $\mathrm{C} / \mathrm{EBP} \alpha, \mathrm{C} / \mathrm{EBP} \beta$, or $\mathrm{C} / \mathrm{EBP} \delta, \mathrm{Rb}$, or $422 / \mathrm{aP} 2 / \mathrm{C} / \mathrm{EBP} \alpha, \mathrm{C} / \mathrm{EBP} \beta$, and C/EBP $\delta$ and $422 / \mathrm{aP} 2$ antibodies were prepared in this laboratory; $\mathrm{Rb}$ antibody was purchased from Promega). To detect C/EBP $\beta$ protein in proliferating preadipocytes, $80 \%$ confluent proliferating preadipocytes were treated with or without MIX for $4 \mathrm{hr}$ after which whole cell extracts were prepared and Western blotted as described above.

For alkaline phosphatase treatment cell lysates $(\sim 200 \mu \mathrm{g}$ of protein) were incubated for $30 \mathrm{~min}$ at $37^{\circ} \mathrm{C}$ without or with 100 units of calf intestinal alkaline phosphatase (Boehringer Mannheim) in $60 \mu \mathrm{l}$, followed by the addition of 100 units of phosphatase and incubation for another 30 min under the same con- 
ditions. The reaction mixtures were then subjected to immunoblotting with anti-Rb antibody.

\section{$\left[{ }^{3} H\right]$ Thymidine incorporation}

At various times after induction of differentiation, two $35-\mathrm{mm}$ cell monolayers were pulse-labeled with $\left[{ }^{3} \mathrm{H}\right]$ thymidine $(1 \mu \mathrm{Ci} /$ $\mathrm{ml}$ ) for $15 \mathrm{~min}$, then washed twice with cold phosphate-buffered saline (pH 7.5), extracted with $2 \mathrm{ml}$ of $0.5 \mathrm{M} \mathrm{KOH}$, and chromosomal DNA precipitated with $4 \mathrm{ml}$ of $20 \%$ TCA on ice for 15 min. The DNA was filtered onto GF/C glass microfibre filters (Whatman), washed with 95\% ethanol, dried and counted.

\section{Immunofluorescence microscopy}

3T3-L1 preadipocytes were plated onto coverslips in $35-\mathrm{mm}$ dishes at the same cell density as usual and then induced to differentiation as above. At various times thereafter, cell monolayers were washed with cold PBS, fixed with $4 \%$ formaldehyde in PBS on room temperature for $20 \mathrm{~min}$; permeabilized with $0.075 \%$ Triton X-100 in $2 \mathrm{mg} / \mathrm{ml} \mathrm{BSA}$ in PBS for $30 \mathrm{~min}$; and blocked with $2 \mathrm{mg} / \mathrm{ml}$ BSA in PBS for 1-2 hr at room temperature. Cells were incubated with the first antibody $(\mathrm{C} / \mathrm{EBP} \alpha$, $\mathrm{C} / \mathrm{EBP} \beta$, or C/EBP $\delta$ antibody at $1: 1000$ dilution) in $2 \mathrm{mg} / \mathrm{ml}$ BSA in PBS for 1-2 $\mathrm{hr}$ and then incubated with FITC-labeled second antibody in the same buffer for $1 \mathrm{hr}$. After each step, the cells were washed with PBS three times. Antifade solution (Molecular Probes) was added to the monolayers and mount on slides. For DAPI staining, coverslips were incubated with DAPI (Molecular Probe) for $5 \mathrm{~min}$ and then washed with PBS.

\section{Acknowledgments}

This work was supported by a research grant from the National Institutes of Health [National Institute of Diabetes and Digestive and Kidney Diseases (NIDDKD)]. We thank Drs. Steven McKnight for providing $\mathrm{rC} / \mathrm{EBP} \beta$, William Earnshaw for supplying CENP-B antibody, Adrian Bird and Wolf Stratling for providing mouse satellite DNA vectors, Joseph Gall and Tom Loftus for helpful discussions, and Derrick Robinson for assistance with fluorescence microscopy.

The publication costs of this article were defrayed in part by payment of page charges. This article must therefore be hereby marked 'advertisement' in accordance with 18 USC section 1734 solely to indicate this fact.

\section{References}

Baer, M., S.C. Williams, A. Dillner, R.C. Schwartz, and P.F. Johnson. 1998. Autocrine signals control CCAAT/enhancer binding protein $\beta$ expression, localization and activity in macrophages. Blood 92: 4353-4365.

Bernlohr, D.A., M.A. Bolanowski, T.J. Kelly, and M.D. Lane. 1985. Evidence for an increase in transcription of specific mRNAs during differentiation of 3T3-L1 preadipocytes. I. Biol. Chem. 260: 5563-5567.

Brun, R.P., P. Tontonoz, B.M. Forman, R. Ellis, C. Jasmine, R.M. Evans, and B.M. Spiegelman. 1996. Differential activation of adipogensis by multiple PPAR isoforms. Genes \& Dev. 10: 974-984.

Cao, Z., R.M. Umek, and S.L. McKnight. 1991. Regulated expression of three C/EBP isoforms during adipose conversion of 3T3-L1 cells. Genes \& Dev. 5: 1538-1552.

Cheneval, D., R.J. Christy, D. Geiman, P. Cornelius, and M.D. Lane. 1991. Cell-free transcription directed by the 422 adi- pose P2 gene promoter: Activation by the CCAAT/enhancer binding protein. Proc. Nat1. Acad. Sci. 88: 8465-8469.

Christy, R.J., V.W. Yang, J.M. Ntambi, D.E. Geiman, W.H. Landschulz, A.D. Friedman, Y. Nakabeppu, T.J. Kelly, and M.D. Lane. 1989. Differentiation-induced gene expression in 3T3-L1 preadipocytes: CCAAT/enhancer-binding protein interacts with and activates the promoters of two adipocytespecific genes. Genes \& Dev. 3: 1323-1335.

Christy, R.J., K.H. Kaestner, D.E. Geiman, and M.D. Lane. 1991. CCAAT/enhancer binding protein gene promoter: Binding of nuclear factors during differentiation of 3T3-L1 preadipocytes. Proc. Natl. Acad. Sci. 88: 2593-2597.

Cornelius, P., O.A. MacDougald, and M.D. Lane. 1994. Regulation of adipocyte development. Annu. Rev. Nutr. 14: 99-129.

Descombes, P. and U. Schibler. 1991. A liver-enriched transcriptional activator protein, LAP, and a transcriptional inhibitory protein, LIP, are translated from the same mRNA. Cell 67: 569-579.

Earnshaw, W.C., H.I. Ratrie, and G. Stetten. 1989. Visualization of centromere proteins CENP-B and CENP-C on a stable dicentric chromosome in cytological spreads. Chromosoma 98: $1-12$.

Hatakeyama, M. and R.A. Weinberg. 1995. The role of Rb in cell cycle control. Prog. Cell Cycle Res. 1: 9-19.

Hendrich, B. and A. Bird. 1998. Identification and characterization of a family of mammalian methyl-CpG binding proteins. Mol. Cell. Biol. 18: 6538-6547.

Herrera, R., H.S. Ro, G.S. Robinson, K.G. Xanthopoulos, and B.M. Spiegelman. 1989. A direct role for C/EBP and the AP-I binding site in gene expression linked to adipocyte differentiation. Mol. Cell. Biol. 9: 5331-5339.

Horz, W. and W. Altenburger. 1981. Nucleotide sequence of mouse satellite DNA. Nucleic Acids Res. 9: 683-696.

Hwang, C.-S., S. Mandrup, O.M. MacDougald, D.E. Geiman, and M.D. Lane. 1996. Transcriptional activation of the mouse obese gene by CCAAT/enhancer binding protein $\alpha$. Proc. Natl. Acad. Sci. 93: 873-877.

Hwang, C.-S., T. Loftus, S. Mandrup, and M. Lane. 1997. Adipocyte differentiation and leptin expression. Annu. Rev. Cell Biol. Dev. 13: 231-259.

Joseph, A., A.R. Mitchell, and O.J. Miller. 1989. The organization of the mouse satellite DNA at certromere. Exp. Cell Res. 183: 494-500.

Kaestner, K.H., R.J. Christy, and M.D. Lane. 1990. Mouse insulin-responsive glucose transporter gene: Characterization of the gene and trans-activation by the CCAAT/enhancer binding protein. Proc. Natl. Acad. Sci. 87: 251-255.

Lavery, D.J. and U. Schibler. 1993. Circadian transcription of the cholesterol $7 \alpha$ hydroxylase gene may involve the liverenriched bZIP protein DBP. Genes \& Dev. 7: 1871-1884.

Lin, F.-T. and M.D. Lane. 1992. Antisense CCAAT/enhancerbinding protein RNA suppresses coordinate gene expression and triglyceride accumulation during differentiation of 3T3L1 preadipocytes. Genes \& Dev. 6: 533-544.

. 1994. CCAAT/enhancer-binding protein $\alpha$ is sufficient to initiate the 3T3-L1 adipocyte differentiation program. Proc. Natl. Acad. Sci. 91: 8757-8761.

Lin, F.-T., O.A. MacDougald, A.M. Diehl, and M.D. Lane. 1993. A 30-kilodalton alternative translation product of the CCAAT/enhancer-binding protein $\alpha$ message: Transcriptional activator lacking antimitotic activity. Proc. Nat1. Acad. Sci. 90: 9606-9610.

MacDougald, O.A. and M.D. Lane. 1995. Transcriptional regulation of gene expression during adipocyte differentiation. Annu. Rev. Biochem. 64: 345-373.

MacDougald, O.A., P. Cornelius, F.-T. Lin, S.S. Chen, and M.D. 
Lane. 1994. Glucocorticoids reciprocally regulate expression of the CCAAT/enhancer-binding protein $\alpha$ and $\delta$ genes in 3T3-L1 adipocytes and white adipose tissue. J. Biol. Chem. 269: 19041-19047.

MacDougald, O.A., P. Cornelius, R. Liu, and M.D. Lane. 1995. Insulin regulates transcription of the CCAAT/enhancerbinding protein $(\mathrm{C} / \mathrm{EBP}) \alpha, \beta$, and $\delta$ genes in fully-differentiated 3T3-L1 adipocytes. J. Biol. Chem. 270: 647-654.

Masumoto, H., H. Masukata, Y. Muro, N. Nozaki, and T. Okazaki. 1989. A human centromere antigen (CENP-B) interacts with a short specific sequence in alphoid DNA, a human centromeric satellite. J. Cell Biol. 109: 1963-1973.

Miller, O.L., W. Schnedl, J. Allen, and B.F. Erlanger. 1974. Immunofluorescent localization of 5MC. Nature 252: 636-637.

Reed, S.I. 1997. Control of the $\mathrm{G}_{1} / \mathrm{S}$ transition. Cancer Surv. 29: 7-23.

Samuelsson, L., K. Stromberg, K. Vikman, G. Bjursell, and S. Enerback. 1991. The CCAAT/enhancer binding protein and its role in adipocyte differentiation: Evidence for direct involvement in terminal adipocyte development. EMBO J. 10: 3787-3793.

Stephanova, E., V. Russanova, Y. Chentsov, and I. Pashev. 1988. Mouse centromeric heterochromatin: Isolation and some characteristics. Exp. Cell Res. 179: 545-553.

Student, A.K., R.Y. Hsu, and M.D. Lane. 1980. Induction of fatty acid synthetase synthesis in differentiating 3T3-L1 preadipocytes. J. Biol. Chem. 255: 4745-4750.

Tanaka, T., N. Yoshida, T. Kishimoto, and S. Akira. 1997. Defective adipocyte differentiation in mice lacking the $\mathrm{C} / \mathrm{EBP} \beta$ and/or C/EBPS gene. EMBO J. 16: 7432-7443.

Tang, Q.-Q., M.-S. Jiang, and M.D. Lane. 1999. Repressive effect of $\mathrm{Sp} 1$ on the $\mathrm{C} / \mathrm{EBP} \alpha$ gene promoter: Role in adipocyte differentiation. Mol. Cell. Biol. 19: 4855-4865

Timchenko, N., M. Wilde, M. Nakanishi, J. Smith, and G. Darlington. 1996. CCAAT/enhancer-binding protein alpha (C) EBP alpha) inhibits cell proliferation through the p21 (WAF1/CIP-1/SDI-1) protein. Genes \& Dev. 10: 804-815.

Timchenko, N.A., T.E. Harris, M. Wilde, T.A. Bilyeu, B.L. Burgess-Beusse, M.J. Finegold, and G.J. Darlington. 1997. CCAAT/enhancer-binding protein alpha regulates $\mathrm{p} 21$ protein and hepatocyte proliferation in newborn mice. Mol. Cell. Biol. 17: 7353-7361.

Trautwein, C., P. van der Geer, M. Karin, T. Hunter, and M. Chojkier. 1994. Protein kinase A and C site-specific phosphorylations of LAP (NF-IL6) modulates its binding to DNA recognition elements. J. Clin. Invest. 93: 2554-2561.

Umek, R.M., A.D. Friedman, and S.L. McKnight. 1991. CCAAT-enhancer binding protein: A component of a differentiation switch. Science 251: 288-292.

Wang, N., Finegold, M.J., A. Bradley, Ou, C.N., Abdelsayed, S.V., Wilde, M.D., Taylor, L.R., Wilson, D.R. and G.J. Darlington. 1995. Impaired energy metabolism in $\mathrm{C} / \mathrm{EBPa}$ knock-out mice. Science 269: 1108-1112.

Williams, S.C., M. Baer, A.J. Dillner, and P.F. Johnson. 1995. CRP2/C/EBP beta) contains a bipartite regulatory domain that controls transcriptional activation, DNA binding and cell specificity. EMBO J. 14: 3170-3183.

Yeh, W.-C., Z. Cao, M. Classon, and S.L. McKnight. 1995. Cascade regulation of terminal adipocyte differentiation by three members of the C/EBP family of leucine zipper proteins. Genes \& Dev. 9: 168-181. 


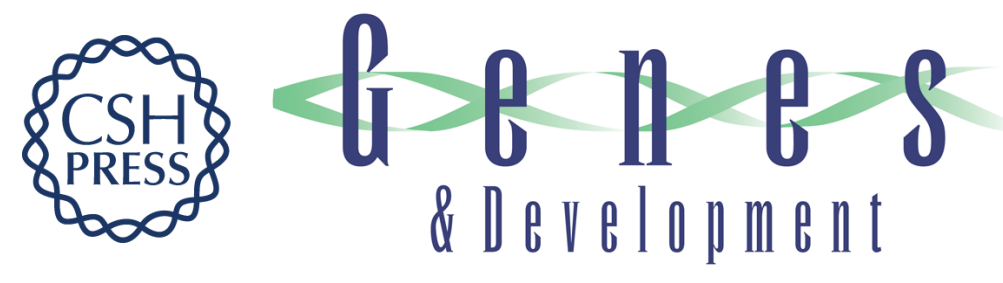

\section{Activation and centromeric localization of CCAAT/enhancer-binding proteins during the mitotic clonal expansion of adipocyte differentiation}

Qi-Qun Tang and M. Daniel Lane

Genes Dev. 1999, 13:

References

This article cites 39 articles, 26 of which can be accessed free at:

http://genesdev.cshlp.org/content/13/17/2231.full.html\#ref-list-1

License

Email Alerting

Service

Receive free email alerts when new articles cite this article - sign up in the box at the top right corner of the article or click here.

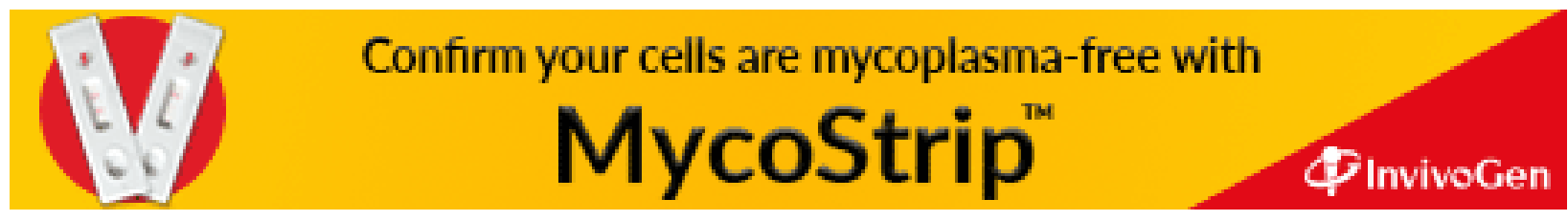

